\title{
Revitalization of State Defense Through Military Operations Other Than War "Civic Mission" During the COVID-19 Pandemic
}

\author{
Ratu Aulia ${ }^{1, *}$, Cecep Darmawan ${ }^{2}$
}

\author{
1,2 Universitas Pendidikan Indonesia, Bandung, Indonesia \\ ${ }^{*}$ Corresponding author. Email: ratuaulia@upi.edu
}

\begin{abstract}
This study aims to determine the revitalization of state defense through Military Operations Other Than War (MOOTW) "Civic Mission" during the COVID-19 pandemic. Since the COVID-19 pandemic has spread throughout the world and Indonesia. This pandemic has made the awareness of defending the country more vulnerable, the people's thinking has transformed from collectivism to individualism so that it will threaten the existing spirit of defending the country. Every citizen is obliged to defend his country so that the survival of his nation is maintained. To defend the country is determined by how the attitude and behavior of each citizen. If citizens are active and care about the progress of their nation, the survival of their nation will be maintained. On the other hand, if citizens do not care about the problems faced by their nation, then the survival of the nation will be threatened and sooner or later the country will be destroyed. The research design used is a qualitative approach with a descriptive method. The results of this study indicate that in the 1945 Constitution of the Republic of Indonesia has explicitly regulated the obligations of Indonesian citizens without exception to participate in efforts to defend the country. The spirit of defending the country, one of which is the MOOTW effort which is expected to be able to internalize and inspire us as citizens to remain united during the COVID-19 pandemic.
\end{abstract}

Keywords: COVID-19, Military Operations Other Than War, State Defense.

\section{INTRODUCTION}

Corona Virus or SARS-Cov-2 is a pandemic that attacks the world by infecting the human respiratory tract and threatening all lines of human life, the virus, which is familiarly known as COVID-19, was first discovered in Wuhan, China at the end of 2019 and later infected more than 65.1 million and kills no less than 1.5 million people in the world [1]. Most countries in the world, only realized the dangers of COVID-19 in the range of February - March so they could not prepare conditions to prevent the negative impact of the spread of this virus [2]. Until finally the World Health Organization (WHO) declared this virus to be a pandemic on March 11, 2020 [2][1].

According to the World Bank [3] the crisis caused by the spread of the COVID-19 pandemic is the most severe crisis due to a pandemic since the 1900s. One of the countries that are not ready to face the spread of COVID19 is Indonesia [4]. This is based on data that the Indonesian economy decreased by 2.07 percent from the previous [5], economic growth slowed to $2.97 \%$ per year in the first quarter of 2020 and contracted $5.32 \%$ per year in the second quarter of 2020 [6]. It has been a year since the turmoil from the COVID-19 pandemic attacked Indonesia, resulting in various sectors within the Indonesian state experiencing paralysis which threatens national stability [7].

Sugito and Aulia [8] view that nationalism is different in each country, this is due to their different historical backgrounds, nationalism is the most amazing social invention in the course of human history, at least in the last hundred years. However, one area that has also declined in this pandemic attack is love for the country and nationalism in society [32][10]. then the uncontrolled flow of information and hoax news developed massively due to the policy to stay at home so that people's access to spend more time on their mobile phones [11]. This is exacerbated by some government officials who have corrupted the COVID-19 social assistance funds [12], causing public distrust of government officials and causing the degradation of the values of defending the 
state in Indonesian people, even though defending the country is one of the pillars of in maintaining the survival of the country. From the problems that have been described, it is known that the important role of defending the state in maintaining the integrity of the state is very large in order to maintain state sovereignty so that the state can survive in the face of all threats that come both from outside and from within the country.

These changes require a new form of state defense in the face of asymmetric war. The paradigm that develops in society means that defending the country in Indonesia is always related to militarism which is synonymous with rigidity, uniform, and carrying weapons, but actually defending the country can also be carried out to fight wars in the modern era or what is also called proxy war, the war is carried out against a negative culture that enters the country, drugs, and the war against cohabitation which has the potential to destroy Indonesia's young generation [14].

Shalikashvili [15] defines MOOTW as focusing on preventing war, resolving conflicts, promoting peace, and supporting large-scale civilian authorities in order to safeguard the national interests of a country. Military Operations Other than War (MOOTW) in Indonesia is a program carried out by the TNI in order to maximize its function as a tool in efforts in the defense sector in upholding state sovereignty [13]. This article aims to find out the revitalization of national defense through military operations other than the "civic mission" war during the COVID-19 pandemic.

\section{THEORETICAL REVIEW}

\subsection{State Defense}

Efforts to defend the state have dimensions that are interrelated with one another (geographical, psychological, security and dedicated) [16]. Meanwhile, the explanation of Article 9 paragraph (1) of Law no. 3 of 2002 concerning National Defense [17] explains that defending the country is an act of every individual who reflects Pancasila and the 1945 Constitution of the Republic of Indonesia as a sense of nationalism to his country. From this explanation, it is understood that defending the country is the responsibility of every component of the state in protecting, safeguarding and defending the country.

Meanwhile, according to Asley [18] suggests that the activities of citizens who defend the nation and state are either in the form of thoughts or actions. State defense activities are carried out by facing threats that are aimed at and hinder the interests and sovereignty of the state Erlington [18]. Then Kinsey [18] is of the view that state defense activities are a representation of the nationalism and patriotism of citizens who are the source of state power. The statement emphasized that a country also has its own national needs which can be realized by means of defending the country which is imposed on all its citizens.

\subsection{Military Operations Other Than War}

Theoretically, military operations other than war are the use of the "idle capacity" of military organizations in peacetime. The involvement of the TNI in handling the COVID-19 pandemic tends to be influenced by three risk factors, namely the level of transmission of the disease outbreak, the ability of civil institutions to handle it and the impact of the pandemic on socio-political stability. According to Law Number 34 of 2004 concerning the Indonesian National Army [20] specifically regulates 14 types of MOOTW forms, at points 12 and 13 regulate the response to natural disasters, evacuation and the provision of humanitarian assistance and assistance in accidents (Search and Rescue). Although COVID-19 is included in the non-natural category, the implementation of MOOTW can still be carried out based on the regulation of the Minister of Defense (Permenhan) Number 9 of 2011 which describes that the main task of the TNI in the process of natural disaster management, one of the efforts in disaster management can be done with humanitarian assistance. Humanitarian assistance referred to here is assistance given to the community to eliminate all kinds of disturbances and loss of human nature and dignity that can be caused by both natural and non-natural disasters. So that by referring to the Minister of Defense, the TNI can involve itself in Military Operations Other than War in helping people affected by this pandemic by entering the category of humanitarian assistance.

\section{METHODS}

This study uses a qualitative approach, this is because this approach involves discoveries in natural or "naturalistic" models that allow researchers to develop a higher level of detail from actual experience [21]. The reason the researcher uses a qualitative approach is that the data analysis process used is qualitative, namely in the process of collecting, analyzing and compiling the data and making decisions not using systematic numerical calculations or inferential statistics.

While the research method used is descriptive which seeks to describe various information by conducting a critical analytical study of the information or data obtained. The participants in this study were Law Number 34 of 2004 concerning the Indonesian National Army [20] and an official of the Indonesian Ministry of Defense, namely Widya Iswara Pusdiklat State Defense Bagdiklat.

This study uses two types of data in the form of primary data and secondary data, the data obtained by researchers directly from the literature study conducted by researchers in obtaining data by conducting searches and reviewing literature related to the problems to be observed by exploring and exploring concepts along with theories or arguments. The basic data that was initiated by experts as well as the literature archives from the organizers of the state defense awareness program are called primary data, while the secondary data was 
selected by researchers from interviews with Indonesian Ministry of Defense officials, namely Widya Iswara Pusdiklat for State Defense Bagdiklat. The data collection techniques used are documentation and interviews. While the data analysis technique used is an interactive model qualitative data analysis according to Miles, Matthew B and A. Michael Huberman [22] which consists of three activities occurring simultaneously, namely 1) Data reduction, 2) Data presentation, 3) Drawing conclusions/Verification.

\section{FINDINGS AND DISCUSSION}

\subsection{TNI MOOTW Regulations}

If we look at the implementation of the TNI's MOOTW during the COVID-19 pandemic, it is based on several regulations made by the Indonesian government, both laws and decisions that strengthen the TNI to be involved in efforts to defend the country through Military Operations Other than War. Article 4 of Law Number 24 of 2007 concerning Disaster Management explains that the goal in the disaster management process is to "harmonize the existing laws and regulations ... and create peace in the life of society and the state". This can be interpreted that this law is the basis and core reference in ensuring the implementation of disaster management in a planned, integrated, coordinated, and comprehensive manner and intersects with the duties and functions of the TNI as an institution that guarantees peace and harmony in the life of society and the state [24].

Then, it was reaffirmed that the participation of the TNI as an institution that could be involved in disaster management was one of the 14 points in Article 50 which explains if the state is in a disaster emergency, BNPB has access to give orders to sectors or state institutions such as the TNI. Based on this regulation, Presidential Decrees No. 7 and 9 of 2020 were made regarding the formation of a task force in the context of accelerating the handling of COVID-19, chaired by liutenant General Doni Monardo and the deputy chairman of his task force are one of the assistant officers to the TNI Commander [25].

The next constitutional basis is to refer to Law Number 3 of 2002 concerning National Defense in article 10 point three where the TNI implements state defense policies through MOOTW during the COVID-19 pandemic which is a non-military disaster that threatens national defense so that the TNI is obliged to help the acceleration of response due to the impact of the COVID19 pandemic on the Indonesian people, either based on assignments or legislation [19].

Law Number 34 of 2004 concerning the Indonesian National Armed Forces specifically regulates 14 types of MOOTW forms, at points 12 and 13 it regulates the response to natural disasters, evacuation, and the provision of humanitarian assistance and assistance in accidents (Search and Rescue) [20]. Although COVID-
19 is included in the category of non-natural disasters, the implementation of MOOTW can still be carried out based on the regulation of the Minister of Defense (Permenhan) No. 9 of 2011 which describes that the main task of the TNI in the process of natural disaster management, one of the efforts in disaster management can be done with assistance. Humanity, humanitarian assistance in question is assistance provided to the community where the community is disturbed and the loss of human nature and dignity that can be caused by natural and non-natural disasters [26]. So that by referring to the Minister of Defense, the TNI can involve itself in Military Operations Other than War in helping people affected by this pandemic by entering the category of humanitarian assistance.

The next regulation is Law Number 6 of 2018 concerning Health Quarantine [27], referring to the law, So the Indonesian government issued Presidential Decree No. 11 of 2020 concerning Emergency Citizens Due to the Covid Pandemic and Presidential Regulation No. 21 of 2020 concerning PSBB as an effort to prevent the widespread of the COVID-19 pandemic [28], the MOOTW task carried out by the TNI by helping the local government and the police in maintaining public security and order, and finally the Government Regulation in Lieu of Law (Perppu) Number 23 of 1959 which regulates emergency conditions and dangers, whether there is armed conflict, physical threats to the state or other threats such as the COVID-19 pandemic. 19 which endangers the life of the state. This regulation stipulates that the government can declare three categories of state of emergency either partially or completely in the territory of Indonesia, namely the first is a civil emergency, second is a military emergency, and last is war [29]. This law is at risk of asserting civil liberties which will trigger polemics and opposition in civil society.

\subsection{State Defense Revitalization in MOOTW}

State defense is an effort made to protect the country from threats, disturbances, and obstacles both from within the country and outside. Because it is an effort to defend the state is an obligation and is the responsibility of every citizen from various classes of society, state defense activities are carried out to maintain the honor and dignity of the state [30][31][21]. In addition, Pancasila can provide solutions to every problem faced by Indonesia as it is today during the COVID-19 pandemic and can be an antidote or prevention against negative influences from outside cultures that can damage the integrity of the Indonesian state [32][11].

According to Subagyo (2015) philosophically defending the state is a form of practice from the theory of social agreement regarding the formation of a state [33]. Where the adherents of this theory are of the view that the desire of the community in an effort to protect their obligations and rights so that peace, peace, and harmony are created are elements that make up a country. Each 
country has ways and concepts in defending the country in various forms that are adapted to the goals and ideology of the country [34].

Efforts to defend the country during the pandemic require that every component of the nation with different backgrounds must be able to hold on to each other, strengthen social cohesion, maintain unity, form harmony in every difference that exists based on the spirit of cooperation as the national identity [10]. One form of state defense carried out by the Indonesian National Armed Forces (TNI) in the face of the COVID-19 pandemic is to revitalize efforts to defend the country that is capable of dealing with a new style of war called asymmetric war. Revitalization is one of the efforts to revive or re-enact a culture and tradition that maintains the foundations of civilization to survive in its life [35]. The revitalization effort carried out by the TNI is to carry out Military Operations Other Than War (MOOTW).

MOOTW makes the military not always the main role but more sensitive to political considerations [15][36]. The implementation of MOOTW in Indonesia is a form of synergy between organizational institutions, both government and non-government, the form of synergy that is usually carried out is related to diplomacy, politics, government, and religion [37]. Ayers [23] state has three components of a national military strategy, namely: a) involvement in peacetime; b) conflict prevention; and c) fight and win the nation's war. The first point is a reflection of the important role of MOOTW as a forum for conflict prevention and the involvement of soldiers in peacetime. This is a form of state defense carried out by the TNI in accelerating recovery during the pandemic.

The first national strategy during the pandemic is to maintain and strictly control unlimited resources such as human resources, materials, financial and medical resources to control the balance during this pandemic. the second is the rough rationality strategy, this strategy requires the closure of territorial borders to cut off contact with infected countries and cities that are adjacent to the economic center and territory of our country. policies in the field [38].

The efforts to revitalize state defense through the TNI MOOTW are carried out with humanitarian operations which include three types of operations that include a civic mission, namely: First, medical treatment operations, in this operation the TNI encourages every government effort in dealing with the COVID-19 outbreak to be carried out thoroughly throughout the entire country. In the area, the TNI utilizes the military health corps owned by every military regional command throughout Indonesia and the TNI ensures that health facilities such as hospitals and emergency clinics, military hospitals, and military medical personnel, including nurses, general practitioners, and military specialists, are fully empowered for humanitarian missions in the context of implementing MOOTW during the pandemic.
Second, security operations, based on Presidential Regulation Number 12 of 2020, require every citizen to carry out large-scale social restrictions and the application of health protocols, this is done to reduce the number of spreads of the COVID-19 virus, in practice, the TNI participates in the process of socializing the social restrictions policy. The military is trying to bring order to people who violate and refuse to follow the government's rules. This socialization and security process is carried out on all elements of society with a humanist approach to explain that in a crisis condition the people must be united and compact in implementing health protocols under central and regional government regulations. Security operations are also carried out in the territorial areas of infected countries bordering the Indonesian territory either by TNI AD, TNI AL, and TNI AU. In addition, it is a real manifestation of its security operations by increasing surveillance of strategic areas that can be used by rebels or other countries who want to infiltrate to take advantage of Indonesia's condition which is currently focusing on overcoming the health and economic crisis caused by COVID-19.

During the pandemic period, the TNI carried out security operations for strategic vital state objects to ensure order and smooth supply of basic materials, medical equipment, and national communications. According to Presidential Decree No. 63 of 2004, what is meant by strategic vital state objects are objects that (i) produce basic daily needs; (ii) threats and disturbances to them result in disasters for humanity and development; (iii) threats and disturbances against it result in disruption of transportation and communications nationally; and/or (iv) threats and disturbances to it result in disruption of state administration. With the importance of strategic vital objects of the state, the government will involve TNI troops to maintain strategic facilities such as medical facilities and national logistics facilities, and other facilities that will exacerbate the impact of the COVID-19 pandemic [39].

Third, support operations, this operation is carried out by the TNI by ensuring the distribution of equipment and health logistics needed from the center to the regions or vice versa by utilizing defense equipment such as logistics trucks, military cargo planes, or navy ships. In addition to equipment and health logistics assistance, this operation also facilitates the distribution of social assistance and logistics for food, clothing, food, and soup kitchens to accelerate the response to the negative impacts of the COVID-19 pandemic.

\section{CONCLUSION}

Military operations apart from the war (MOOTW) are one of the efforts of Indonesian armed forces (TNI) in maintaining the country's sovereignty by using soft power, MOOTW activities are included in the category of state defense efforts carried out by the government, in this case, 
the TNI collaborates with non-governmental organizations to carry out humanitarian missions. during the COVID-19 pandemic efforts that can be carried out with three types of operations, namely a) medical handling operations; b) security operation; and c) support operation.

Given that MOOTW tasks often require special equipment, it is necessary careful planning for the operations that are likely to be performed. Various special exercises needs to be done to improve the ability of army personnel in carrying out their duties MOOTW. MOOTW planning needs to consider the implications of increasing MOOTW on doctrine, power structure, and training; to produce a unified force capable of address the entire spectrum of threats and disturbances to national security and resilience. Military institutions need to develop comprehensive planning to ensure that the MOOTW that assigned by the state can be done completely.

\section{AUTHORS' CONTRIBUTIONS}

This paper Presents how to Revitalization of State Defense through Military Operations Other Than War "Civic Mission" During the COVID-19 Pandemic. This article also discusses the regulations that are the basis for efforts to revitalize state defense through Military Operations Other than War during the COVID-19 pandemic, furthermore, this article describes the steps and ways to revitalize efforts to defend the State with Military Operations other than War.

\section{ACKNOWLEDGMENTS}

This article is supported by Nehlah, S.Pd., because she has provided suggestions so that the authoress can complete this article. Then, the authors also conveys to Nuzon Sugito, M.Pd. as proofread of this article and the committee The third Annual Civic Education Conference Universitas Pendidikan Indonesia as a reviewer for

\section{REFERENCES}

[1] D.B.T Magar, S. Pun, R. Pandit, M.F.R. Rubzen, "Pathwaus for Building Resilience to COVID-19 Pandemic and Revitalizing the Nepalese Agriculture Sector", Agricultural Systems, 187, 103022, 2021

[2] M. Menhat, I.M.M, Zaideen, Y, Yusuf,. N.H.M. Salleh, M.A Zamri,. J. Jeevan, "The Impact of COVID-19 Pandemic : A Review on Maritime Sectors in Malaysia”, Ocean and Coastal Management, 209, 2021

[3] World Bank. (2020). COVID-19 Crisis through a Migration Lens. Migration and Development Brief, No. 32 [Online]. Available: https://open knowledge.worldbank.org/bitstream/handle/10 986/33634/COVID-19-Crisis-Through-a

Migration-Lens. pdf? sequence $=5 \&$ is Allowe $\mathrm{d}=\mathrm{y}$.

[4] R.K. Hastuti. (2021). Menkes : Sejak SARS 2003, RI Tak Pernah Siap Hadapi Pandemi [Online]. Available: https://www.cnbcindonesia .com/tech/20210325172638-37232911/menkes -sejak-sars-2003-ri-tak-pernahsiap-hadapi-pandemi.

[5] Badan Pusat Statistik Indonesia. (2021). Ekonomi Indonesia 2020 Turun Sebesar 2.07 Persen [Online]. Available: https://www.bps.go. $\mathrm{id} /$ press release/2021/02/05/1811/ekonomi-indo nesia-2020-turun-sebesar-2-07-persen--c-to-c.html.

[6] Bank Indonesia. (2020). Bersinergi Membangun Optimisme Pemulihan Ekonomi [Online]. Available: https://www.bi.go.id/id/publikasi/lap oran/Documents/LPI_2020.pdf.

[7] P. Ananda. (2020). Pandemi COVID-19 Momentum Wujudkan Semangat Bela Negara [Online]. Available: https://mediaindonesia.com /politik-dan-hukum/341682/pandemi-covid-19momentum-wujud kan-semangat-bela-negara.

[8] N. Sugito, R. Aulia, L. Rukmana, "Pancasila as the Establishing Ideology of Nationalism Indonesian Young Generation", In 1st International Conference on Character Education (ICCE 2020), pp. 177-182. Atlantis Press, 2021.

[9] N. Sugito, R. Aulia, "Nasionalisme dalam Historiografi Buku Ajar Sejarah POLRI Untuk Tamtama POLRI TAHUN 1980", In Seminar Nasional Sejarah, vol. 2, no. 1, 2020.

[10] M. D. Fitrilia. (2020). Menumbuhkembangkan Nilai-Nilai Kebangsaan di Masa Pandemi COVID-19, Majalah Swantara No 34 edisi ke 9 [Online]. Available: http://www.lemhannas.go. id/images

/PublikasiHumas/Swantara/Swantara34-Septem ber2020.

[11] R. Hadyan. (2020). Ternyata Masyarakat Indonesia Banyak Habiskan Waktu di Media Sosial [Online]. Available: https://lifestyle. bisnis.com $/ \mathrm{read} / 2020$

1001/220/1299346/ternyata-masyarakat-indone sia-banyak-habiskan-waktu -di-media-sosial.

[12] A. Najib. (2021). Oknum BPK diduga Ikut Kecipratan Dana Korupsi Bansos Hingga Rp 1 Miliar [Online]. Available: https://yogya.inews 
.id/berita/oknum-bpk-diduga-ikut-kecipratandana-korupsi-bansos-hingga-rp1-miliar.

[13] Dewantara. (2019). Analisis Peran, Fungsi dan Tugas TNI Untuk Menghadapi Ancaman Era Globalisasi [Online]. Available: https://sesko ad.mil.id/admin/file/kajian/62\%20Analisa $\% 20$ Peran\%20fungsi\%20dan\%20Tugas\%20TNI.p df.

[14] K.Z.T. Sidqi, "The Implementation Strategy of State Defense in Schools as Part of National Security", The 3rd Annual International Seminar and Conference on Global Issues (ISCoGI), 2017.

[15] J.M. Shalikashvili, "Joint Doctrine for Military Operations Other Than War", Joint Pub 3-07 Joint Chief of State depaertent of the army united states Of America, 1995.

[16] M. Azhar. "Perspektif Islam Tentang Bela Negara”. Jurnal Ketahanan Nasional, VI(1), April 2001.

[17] Wantannas, "Modul Utama Pembinaan Bela Negara, Modul I: Konsepsi Bela Negara”, Jakarta: Dewan Ketahanan Nasional RI, 2018.

[18] A. Subagyo, "Syarat-Syarat Kesiapan Penyelenggaraan Program Bela Negara", Jurnal Pertahanan, 5 (3), 1-19, 2015.

[19] Undang-Undang Nomor 3 Tahun 2002 tentang Pertahanan Negara.

[20] Undang-Undang Nomor 34 Tahun 2004 tentang Tentara Nasional Indonesia.

[21] J. W. Creswell, "Research design: Qualitative and quantitative approaches", Thousand Oaks, CA: SAGE Publications, 1994.

[22] M. B. Miles, A. M. Huberman, \& J. Saldana, "Qualitative Data Analysis, A Methods Sourcebook, Edition 3", USA: Sage Publications. Terjemahan Tjetjep Rohindi Rohidi, UI-Press, 2014.

[23] J. R. Ayers, "Military Operations Other Than War In Thenew World Order: Analysis Of joint Doctrine For The Coming Era". Graduate Research Paper Faculty of the Graduate School of Logisitics and Acquisition. Management of the Air Force Institute of Technology Air University, 1996.

[24] Undang-Undang Nomor 24 Tahun 2007 tentang Penanggulangan Bencana.

[25] Keputusan Presiden Nomor 7 dan 9 tahun 2020 tentang Perubahan atas Keputusan Presiden Nomor 7 Tahun 2020 tentang Gugus Tugas
Percepatan Penanganan Corona Virus Disease 2019 (COVID-19).

[26] Peraturan Menteri Pertahanan Nomor 9 Tahun 2011 tentang Pokok-Pokok Penyelenggaraan Tugas Bantuan TNI dalam Menanggulangi Bencana Alam, Pengungsian dan Bantuan Kemanusiaan.

[27] Undang-Undang Nomor 6 Tahun 2018 tentang Kekarantinaan Kesehatan.

[28] Keputusan Presiden Nomor 11 Tahun 2020 tentang Pembatasan Sosial Berskala Besar.

[29] Pengganti Undang-Undang (Perppu) Nomor 23 Tahun 1959 tentang Pencabutan UndangUndang Nomor 74 Tahun 1957 (LembaranNegara Nomor 160 Tahun 1957) dan Penetapan Keadaan Bahaya.

[30] L. Anggraeni, C. Darmawan, S.W. Tanshzil, "The Use of Comic-Based Technology: Media Cultivation of Values in the Nation Defense". Advances in Social Science, Education and Humanities Research, vol. 418 2nd Annual Civic Education Conference (ACEC), 2019.

[31] Lieut.-Colonel C. E. de la Poer Beresford p.s.c. The State Defences of Russia, Royal United Services Institution. Journal, 42:250, 14141423, 1898.

[32] R. Aulia, N. Sugito, Hasmika, "Implementation of Pancasila in Developing National Insights During the COVID-19 Pandemic". In 1st International Conference on Character Education (ICCE 2020), pp. 201-207, Atlantis Press, 2021.

[33] A. Subagyo, "The Term of the Readiness in Organizing Ther Defending the State Program", Jurnal Pertahanan, Vol. 5, Nomor 3, Desember 2015.

[34] K. W. Soepandji, \& M. Farid, "Konsep Bela Negara dalam Perspektif Ketahanan Nasional", Jurnal Hukum \& Pembangunan, 48 No. 3, 436456, 2018.

[35] S. H. Djoeffan, "Revitalisasi Pendidikan Sebagai Paradigma Peningkatan Kualitas Bangsa", Jurnal Mimbar, Vol. XX, No. 2, AprilJuni 2004.

[36] C. G. Turregano, \& R. L. Waddell, "From Paradigm to Paradigm Shift: The Military and Operations Other Than War". Journal of Political Science, Vol. 22, No. 1, Article 8, 1994.

[37] Y. Djuyandi, C. Heri, \& W. Hidayat, "Military 
Operation other than war (MOOTW) : Synergy of Indonesian National Armed Force ( TNI) and National Disaster Management Agency (BNPB) In disaster management", Humanities \& Social Sciences Reviews, Eissn 2395-6518, Vol 7, No 4, 111-121, 2019.

[38] A.W. Ding, \& S. Li, "National Response Strategies and Marketing Innovations During The COVID-19 Pandemic", Business Horizons, 64, 295e306, 2021.

[39] Peraturan Presiden Nomor 12 Tahun 2020 tentang Penetapan Bencana Non-alam Penyebaran Corona Virus Disease 2019 (COVID-19) Sebagai Bencana Nasional. 